\title{
ECG changes in birth asphyxia and its correlation with Cardiac troponin-I
}

\author{
Pal P $\mathbf{P}^{1}$, Goel $\mathbf{M}^{2}$ \\ ${ }^{1}$ Dr Pankaj Pal, Assistant Professor, Department of Paediatrics, ${ }^{2}$ Dr Manjusha Goel, Associate Professor , Department of \\ Paediatrics. Both are affiliated with Gandhi Medical College, Bhopal, MP.
}

Address for correspondence: Dr Pankaj Pal, Email: roshanchanchlani@gmail.com

\begin{abstract}
Introduction: Cardiac dysfunction is well known in perinatal asphyxia caused by transit myocardial ischemia. Sometimes cardiac dysfunction may be so severe that it can cause congestive cardiac failure and shock that leads to death of newborn. ECG and serum levels of cardiac enzymes can be used to demonstrate impaired myocardial function. Material and Methods: It was a case control study conducted in the department of paediatrics, Gandhi Medical College, Bhopal over a period of 12 months from January 2013 to December 2013. Forty asphyxiated full term neonates were taken as cases and 20 healthy full term neonates as controls. Forty neonates with asphyxia admitted to NICU with gestational age $>37$ completed weeks and with birth weight $>2 \mathrm{~kg}$ taken as cases and twenty healthy full term neonates (37 completed wks) unasphyxiated weighing $>2 \mathrm{~kg}$ at birth with clear liquor and $1 \mathrm{~min}$ Apgar score $>7$. Results: Myocardial dysfunction was present in $90 \%$ of the newborns with severe birth asphyxia and $40 \%$ of newborns with moderate birth asphyxia. $\mathrm{T}$ wave changes were seen in $80 \%$ neonates with severe asphyxia and $33 \%$ neonates with moderate asphyxia. In present study, cTn I levels in severely asphyxiated neonates were significantly higher than moderately asphyxiated neonates and control group neonates (4.6 ng/ml, range $2.1-7.8$, and $1.8 \mathrm{ng} / \mathrm{ml}$, range $0.2-4.8 \mathrm{ng} / \mathrm{ml}$ and $0.6 \mathrm{ng} / \mathrm{ml}$, range $0.2-1 \mathrm{ng} / \mathrm{ml}$ respectively). Conclusion: We found a linear relationship between levels of cardiac troponin-I and birth asphyxia. Therefore cardiac troponin-I level may be useful in predicting the mortality and outcome in perinatal asphyxia.
\end{abstract}

Key words: Birth Asphyxia, Electrocardiography, Cardiac Troponin I, Neonates.

\section{Introduction}

In India, the incidence of perinatal asphyxia is as high as $8.4 \%$ (considering the definition of birth asphyxia as Apgar score of $<7$ at $1 \mathrm{~min}$ ) [1]. Perinatal asphyxia is one of the leading cause of neonatal mortality (28\%) in our country and it is the most common and important cause of preventable cerebral injury occurring in the neonatal period [2]. Perinatal asphyxia affects almost all organ systems of body. In most of the cases multiple organs are involved but sometimes brain may be the only organ exhibiting dysfunction following asphyxia.

Perinatal asphyxia leading to hypoxic-ischemic encephalopathy (HIE) is a common problem causing multi organ dysfunction including myocardial involvement which can affect the outcome [3]. Sometimes cardiac dysfunction may be so severe that it can cause congestive cardiac failure and shock that leads to death newborn. ECG and serum levels of cardiac enzymes can be used to demonstrate impaired myocardial function.

Manuscript received: $1^{\text {st }}$ Apr 2015

Reviewed: $12^{\text {th }}$ Apr 2015

Author Corrected: $6^{\text {th }}$ May 2015

Accepted for Publication: $20^{\text {th }}$ May 2015

International Journal of Medical Research and Review
Cardiac troponins $\mathrm{T}$ and $\mathrm{I}$ are the preferred markers for myocardial injury as they have the highest sensitivities and specificities for the diagnosis of acute myocardial infarction [4].

Cardiac troponin is a protein released from myocytes when irreversible myocardial damage occurs. It is highly specific to cardiac tissue and accurately diagnoses myocardial infarction with a history of ischaemic pain or ECG changes reflecting ischaemia. Cardiac troponin level is dependent on infarct size, thus providing an indicator for the prognosis following an infarction [5].

Studies of cardiac troponin I (cTnI) in newborns are very limited and less diagnostic because of wide range of serum cTnI I concentrations in newborns. cTnI concentrations $>1 \mathrm{ng} / \mathrm{ml}$ in asphyxiated newborns may be considered significant.

ECG changes have been linked to the myocardial ischemia in newborns which include generalized T-wave inversion or flattening, ST segment elevation or depression, abnormal Q wave and bundle branch block.

Available online at: www.ijmrr.in 400 | P a g e 


\section{Research Article}

\section{Material and Methods}

It was a case control study conducted in the department of paediatrics, Gandhi Medical College, Bhopal over a period of 12 months from January 2013 to December 2013.

\section{Sample size}

Forty asphyxiated full term neonates were taken as cases and 20 healthy full term neonates as controls.

\section{Study group}

Forty neonates with asphyxia admitted to NICU with gestational age >37 completed weeks and with birth weight $>2 \mathrm{~kg}$.

\section{Inclusion criteria}

All cases referred from Sultania Zanana hospital with the diagnosis of HIE bases on clinical history at birth and Sarnat and Sarnat staging [6].

\section{Exclusion criteria}

1. Newborns with congestive heart disease

2. Newborns with congenital malformations

3. Metabolic disorders

4. Preterm newborn (>37wks)

\section{Control group}

Twenty healthy full term neonates (37 completed wks) unasphyxiated weighing $>2 \mathrm{~kg}$ at birth with clear liquor and 1 min Apgar score>7.

Clinical examination: A detailed history was taken and complete physical, neurological and cardiovascular examination was done on admission and 48-72 hrs.

\section{Electrocardiogram recording}

ECG was recorded around 48-72 hours of age. during ECG recording calibration factor fixed at 1 standardization that indicate $1 \mathrm{mv}$ equal to $10 \mathrm{~mm}$ for the six limb leads and six precordial leads. Recording speed of paper was $25 \mathrm{~mm} / \mathrm{sec}$. The electrocardiogram was recorded using the ECG machine lead I, II, III, avr, avl and avf were recorded in direct sequence using neonatal section electrodes. ECG scores were calculated by using the scoring system developed by R Jedeikin [7].

\section{Method of determining Cardiac troponin I}

The SD bioline troponin I rapid test was used. It is rapid immune chromatographic assay for the qualitative detection of cTnI in human blood, serum and heparin plasma as an aid in the diagnosis of myocardial ischemia. Two $\mathrm{ml}$ of whole blood is collected in collection vial by venupuncture under aseptic precaution and then centrifuge to get plasma specimen by using dropper. Specimen is taken up to the fill line, then specimen is added into the sample well of the test device and result read at 15 minutes.

\section{Results}

The present study included 60 subjects of which 40 were cases of perinatal asphyxia of moderate to severe degree and 20 were healthy neonates without any evidence of asphyxia as controls. The asphyxiated cases were further divided into two groups on the basis of severity of hypoxic ischemic encephalopathy (HIE). Group A (HIE III) had 10 cases and group B (HIE II) had 30 cases, group $\mathrm{C}$ served as controls.

Table No. 1: Distribution of the newborns into various groups

\begin{tabular}{|l|l|l|l|l|l|}
\hline Category & Degree of Asphyxia & \multirow{2}{*}{ No. of Neonates } & \multicolumn{2}{|l|}{ Sex } & \multirow{2}{*}{ Group } \\
\cline { 4 - 5 } & & & Male & Female & \\
\hline HIE staging III & Severe & $10(25 \%)$ & $7(70 \%)$ & $3(30 \%)$ & A \\
\hline HIE staging II & Moderate & $30(75 \%)$ & $21(70 \%)$ & $9(30 \%)$ & B \\
\hline Normal & Nil & 20 & $13(65 \%)$ & $7(35 \%)$ & C \\
\hline
\end{tabular}

Table No 2: Summary of clinical manifestation as evidence of myocardial dysfunction in birth asphyxia

\begin{tabular}{|l|l|l|}
\hline Myocardial Dysfunction & Group A(n=10) & Group B(n=30) \\
\hline Shock & 2 & 4 \\
\hline Respiratory distress & 4 & 7 \\
\hline Murmur & 2 & 1 \\
\hline CCf & 1 & 0 \\
\hline Total & $\mathbf{9}$ & $\mathbf{1 2}$ \\
\hline
\end{tabular}


Myocardial dysfunction was present in nine (9) newborns with severe birth asphyxia and twelve (12) newborns with moderate birth asphyxia.

Table No 3: Summary of ECG changes in birth asphyxia

\begin{tabular}{|l|l|l|l|l|l|}
\hline Group & $\begin{array}{l}\text { Abnormal } \\
\text { Q wave }\end{array}$ & $\begin{array}{l}\text { Abnormal } \\
\text { T wave }\end{array}$ & $\begin{array}{l}\text { Abnormal ST } \\
\text { segment }\end{array}$ & Prolonged QRS & $\begin{array}{l}\text { Bundle branch } \\
\text { block }\end{array}$ \\
\hline Asphyxiated & 0 & 18 & 6 & 1 & 1 \\
\hline Control & 0 & 9 & 0 & 0 & 0 \\
\hline
\end{tabular}

Table No 4: Jedeikins grading versus HIE cross tabulation

\begin{tabular}{|l|l|l|l|}
\hline \multirow{2}{*}{ Jedkeins grading } & \multicolumn{2}{|l|}{ HIE grading } & \multirow{2}{*}{ Total } \\
\cline { 2 - 3 } & II & III & \\
\hline I & 3 & 0 & 3 \\
\hline II & 7 & 4 & 11 \\
\hline III & 1 & 4 & 5 \\
\hline IV & 0 & 1 & 1 \\
\hline Normal & 19 & 1 & 20 \\
\hline Total & $\mathbf{3 0}$ & $\mathbf{1 0}$ & $\mathbf{4 0}$ \\
\hline
\end{tabular}

\section{Cardiac Troponin I (cTn I)}

In present study, cTn I levels in severely asphyxiated neonates were significantly higher than moderately asphyxiated neonates and control group neonates $(4.6 \mathrm{ng} / \mathrm{ml}$, range $2.1-7.8$, and $1.8 \mathrm{ng} / \mathrm{ml}$, range $0.2-4.8 \mathrm{ng} / \mathrm{ml}$ and $0.6 \mathrm{ng} / \mathrm{ml}$, range $0.2-1 \mathrm{ng} / \mathrm{ml}$ respectively, $\mathrm{P}$ value $<0.005)$

\section{Discussion}

In our study, CVS was the most common organ system to suffer from dysfunction (52.5\%). Similarly in a study conducted by P.S. Rajkumar et al. in 2005, cardiovascular dysfunction was seen in $70 \%$ cases [8]. P. Shah et al. also studied 130 newborns with birth asphyxia and reported cardiovascular dysfunction in $62 \%$ cases [9].

\section{Electrocardiographic Evaluation}

In the present study no significant abnormality of heart rate and rhythm was observed in asphyxiated babies. $\mathrm{T}$ wave changes were seen in $80 \%$ neonates with severe asphyxia and $33 \%$ neonates with moderate asphyxia. Thus the overall incidence was $45 \%$ in asphyxiated babies.

Control group had grade I ECG changes in $45 \%$ cases. Mean axis was 128, which is within normal limit. Prolonged QRS duration was seen in one severely asphyxiated baby. The incidence of RBBB was $10 \%$ in severely asphyxiated babies. No one in the study group showed LBBB. Q wave was normal in all cases. Abnormal ST segment was seen in 50\% neonates with severe asphyxia and $33 \%$ neonates with moderate asphyxia.

Thus the overall incidence was $15 \%$, so according to Jedkeins criteria grade I ECG changes were present in 3
(7.5\%) cases, grade II in $11(27.5 \%)$, grade III in 5 $(12.5 \%)$ and grade IV in $1(2.5 \%)$ cases.

I Barberi et al. reported grade II ECG changes in $100 \%$ cases with moderate asphyxia, grade II in $38.5 \%$, grade III in $38.5 \%$ and grade IV in $23 \%$ cases with severe asphyxia. Control group had $41 \%$ cases with grade I changes that were similar to our present study [10]

Esra Kanik et al. also reported ECG changes in asphyxiated neonates where ECG changes increased with severity of asphyxia [11].

\section{Cardiac Troponin I (cTn I)}

In present study, cTn I levels in severely asphyxiated neonates were significantly higher than moderately asphyxiated neonates and control group neonates (4.6 $\mathrm{ng} / \mathrm{ml}$, range $2.1-7.8$, and $1.8 \mathrm{ng} / \mathrm{ml}$, range $0.2-4.8$ $\mathrm{ng} / \mathrm{ml}$ and $0.6 \mathrm{ng} / \mathrm{ml}$, range $0.2-1 \mathrm{ng} / \mathrm{ml}$ respectively, $\mathrm{P}$ value $<0.005)$. Gulcan turker et al. reported that infants with hypoxia had significantly higher cord blood cTnI levels than normal newborns and in non survivors cord blood cTn I levels were significantly higher than survivors $(5.9 \mathrm{ng} / \mathrm{ml}$, range $2.1-12.8$, and $1.6 \mathrm{ng} / \mathrm{ml}$, range $0.4-5.8 \mathrm{ng} / \mathrm{ml}$ respectively) [12]. 


\section{Research Article}

Esra Kanik et al. studied that serum cTn I level was significantly higher in newborns with birth asphyxia [11]. Danicle Trevisanoto et al. concluded that in asphyxiated neonates, cTn I concentrations were higher with respect to healthy neonates, suggesting the presence of myocardial damage in this group of high risk infants, cTn I did not correlate with traditional marker of asphyxia [13].

\section{Conclusion}

It has been well established that troponin- $\mathrm{T}$ is elevated in myocardial ischemia in perinatal asphyxia. Cardiac troponin-I is specific and sensitive in the diagnosis of cardiac dysfunction in perinatal asphyxia. Mean cardiac troponin-I level in cases with cardiac dysfunction was found significantly higher in cases with severe asphyxia. We found a linear relationship between levels of cardiac troponin-I and birth asphyxia. Therefore cardiac troponinI level may be useful in predicting the mortality and outcome in perinatal asphyxia.

\section{References}

1. National neonatal perinatal database- Report for the year 2002-2003, New Delhi: NNF India 2002. Available online www.newbornwhocc.org/pdf/nnpd_report_2002-03.PDF cited on 10th May 2015.

2. Meharban Singh. Care of the newborn. Sagar publications, $7^{\text {th }}$ ed. April 2010:97-102.

3. Agrawal $\mathbf{J}^{1}$, Shah GS, Poudel P, Baral N, Agrawal A, Mishra OP. Electrocardiographic and enzymatic correlations with outcome in neonates with hypoxicischemic encephalopathy. Ital J Pediatr. 2012 Jul 23;38:33. doi: 10.1186/1824-7288-38-33.

4. Mueller C. Use of high sensitivity troponin for the diagnosis of acute myocardial infarction. Coronary artery Dis. $2013 \quad$ Dec; 24(8):710-2. doi: 10.1097/MCA.0000000000000049.

5. Mia AH, Akter KR, Rouf MA, Islam MN, Hoque MM, Hossain MA, Chowdhury AK. Grading of perinatal asphyxia by clinical parameters and agreement between this grading and Sarnat \& Sarnat stages without measures. Mymensingh Med J. 2013 Oct; 22(4):807-13.
6. Chan D, Ng LL; Biomarkers in acute myocardial infarction. BMC Med. 2010 Jun 7;8:34 doi: 10.1186/1741-7015-8-34.

7. R Jedeikin R, Primhak A, Shennan AT, Swyer PR, Rowe RD. Serial electrocardiographic changes in healthy and stressed neonates. Arch Dis Child 1983;58: 605-611 doi:10.1136/adc.58.8.605.

8. Rajakumar PS, Bhat BV, Sridhar MG, Balachander J, Konar BC, Narayanan P, Chetan G. Cardiac enzyme levels in myocardial dysfunction in newborns with perinatal asphyxiaIndian J Pediatr. 2008 Dec;75(12):1223-5. doi: 10.1007/s12098-008-0242-z. Epub 2009 Feb 4.

9. Shah P, Riphagen S, Beyene J, Perlman M. Multiorgan dysfunction in infants with post-asphyxial hypoxicischaemic encephalopathy. Arch Dis Child Fetal Neonatal Ed. 2004 Mar;89(2):F1525 .

10. Barberi I, Calabrò MP, Cordaro S, Gitto E, Sottile A, Prudente D, Bertuccio G, Consolo S. Myocardial ischaemia in neonates with perinatal asphyxia. Electrocardiographic, echocardiographic and enzymatic correlations. Eur J Pediatr. 1999 Sep; 158(9):742-7.

11. EsraKanik, EsraArun Ozer, Ali RahmiBakiler, HalilAydinlioglu, CoskunDorak, BuketDogrusoz, Ali Kanik, and IsinYaprak. Journal of Maternal-Fetal \& Neonatal Medicine. 2009;22(3):239-242. doi:10.1080/14767050802430834.

12. GülcanTürker, KadirBabaoğlu, Can Duman, Ayşe Gökalp, EmineZengin, Ayşe EnginArısoy. Biol Neonate. 2004;86(2):131-7. Epub 2004 Jun 15. doi: $10.1159 / 000079068$.

13. Trevisanuto D, Picco G, Golin R, Doglioni N, Altinier $\mathrm{S}$, Zaninotto $\mathrm{M}$, Zanardo $\mathrm{V}$. Cardiac troponin $\mathrm{I}$ in asphyxiated neonates. Biol Neonate. 2006; 89(3):190-3. Epub 2005 Nov 17.

Funding: Nil, Conflict of interest: None initiated. Permission from IRB: Yes

\section{How to cite this article?}

Pal P, Goel M. ECG changes in birth asphyxia and its correlation with Cardiac troponin-I. Int J Med Res Rev 2015;3(4):400403. doi: 10.17511/ijmrr.2015.i4.075. 